\title{
COMPARISON OF TWO SLIDE AGGLUTINATION SEROTYPING METHODS AND PCR-BASED CAPSULE TYPING FOR THE CHARACTERIZATION OF HAEMOPHILUS INFLUENZAE SEROTYPES
}

\author{
Maria E.N. Bonifácio da Silva ${ }^{1}$; Paulo da Silva²; Marta I.C. Medeiros²; Suzel N. Neme²; ${ }^{2}$ Claudia Macedo ${ }^{3}$; \\ José Moacir Marin ${ }^{4 *}$
}

${ }^{1}$ Laboratório de Análises Clínicas, Faculdade de Ciências Farmacêuticas de Ribeirão Preto-Universidade de São Paulo, Ribeirão Preto, SP, Brasil; ${ }^{2}$ Secção de Bacteriologia, Laboratório de Ribeirão Preto, Instituto Adolfo Lutz, Secretaria da Saúde de São Paulo, Ribeirão Preto, SP, Brasil; ${ }^{3}$ Departamento de Genética, Faculdade de Medicina de Ribeirão Preto, Universidade de São Paulo, Ribeirão Preto, SP, Brasil; ${ }^{4}$ Departamento de Morfologia, Estomatologia e Fisiologia, Faculdade de Odontologia de Ribeirão Preto, Universidade de São Paulo, Ribeirão Preto, SP, Brasil

Submitted: August 02, 2004; Returned to authors for corrections: May 27, 2005; Approved: January 23, 2006

\section{SHORT COMMUNICATION}

\begin{abstract}
Ninety-three nasopharyngeal Haemophilus influenzae isolates were serotyped by two slide agglutination methods (SAST 1 and SAST 2) and the results compared with those obtained by capsule type-specific PCR. SAST 1 presented a low correlation with results obtained by PCR (75.2\%) while SAST 2 showed a better agreement with the molecular technique results (93.5\%). These findings suggest that SAST 2 could be an alternative method for adequate detection of H.influenzae type b.
\end{abstract}

Key words: Haemophilus influenzae, serotyping methods, PCR

Widespread use of Haemophilus influenzae type b (Hib) conjugate vaccines in industrialized countries has led to nearly complete elimination of $\mathrm{Hib}$ invasive diseases $(6,9,12)$. However, $\mathrm{H}$. influenzae $(\mathrm{Hi})$ remains an important etiological agent of meningitis, septicemia and pneumonia in infants from countries where the Hib vaccine is not accessible (9). In regions where the availability of $\mathrm{Hib}$ conjugate vaccines is low, attendance at a day-care center (DCC) is recognized as a risk factor for invasive $\mathrm{Hib}$ disease (11). DCC was and still is considered a risk factor, as reflected by the increased opportunities for the sharing of respiratory pathogens between children in such settings $(3,5,8)$.

$\mathrm{Hi}$ can express six capsule polysaccharides (serotypes a to f), traditionally identified by slide agglutination serotyping (SAST). Recently however, cases of misidentification of $\mathrm{Hi}$ serotypes by this method have been reported $(1,7)$. To help to overcome this mishap, a SAST method (SAST 2) has been developed in the Adolfo Lutz Institute (1).
A PCR capsule typing method, developed by Falla et al. (4), has been shown to present higher sensitivity and specificity than SAST. The first PCR reaction detected the bexA gene responsible for the transport of capsular material; its presence or absence determines whether an isolate is encapsulated or nonencapsulated and therefore, nontypeable (NTHi). The second PCR assay using capsule type specific primers (a to f) is then used to determine the capsule types of the isolates $(1,4,7)$. The aim of the present study was to verify the discrepancy between slide agglutination methods and the PCR method in the identification of the serotypes of $\mathrm{Hi}$ isolates from healthy carriers of the bacteria.

Between November 2002 and November 2003, a total of 114 children, of either sex aged from 18-36 months, attending three municipal DCCs in Ribeirão Preto, State of São Paulo, were recruited and specimens collected. The research protocol was approved by the Ethics Committee of the School of Dentistry of São Paulo University at Ribeirão Preto, and the study was

*Corresponding Author. Mailing address: Departamento de Morfologia, Estomatologia e Fisiologia, Faculdade de Odontologia de Ribeirão Preto, USP, Av. do Café, s/n, Campus USP. 14040-904, Ribeirão Preto, SP, Brasil. E-mail: jmmarin@ rge.fmrp.usp.br 
initiated with the agreement of the Municipal Service of Health and Education and the approval of the DCC managers. Signed consent was obtained from parents or guardians of the subjects.

Nasopharyngeal samples obtained by using a twisted rayon tipped swab applicator (Copan, Brescia, Italy) in Amies media without charcoal, and plated on the same day, on a selective medium of $10 \%$ sheep blood-chocolate brain heart infusion agar plates, supplemented with $300 \mathrm{mg} / \mathrm{L}$ bacitracin (Difco Laboratories, Detroit, Michigan, USA). After incubation under a $\mathrm{CO}_{2}$-enriched atmosphere at $36^{\circ} \mathrm{C}$, plates were inspected for growth of $\mathrm{Hi}$. Isolates were identified by colony and cell morphology and by the demonstration of growth requirements for $\mathrm{Y}$ and $\mathrm{X}$ factors (2). All strains were kept frozen at $-80^{\circ} \mathrm{C}$ in brain heart infusion broth (Difco) with $40 \%$ glycerol, until further analysis. Isolates were recovered from frozen samples by subculture on chocolate agar plates. Chromosomal DNA was obtained by the Pitcher et al. method (10). Briefly, broth cultures were harvested at the end of the exponential growth phase by centrifugation, pellets were resuspended in Tris- $\mathrm{HCl}$ / EDTA buffer and cells were lysed with guanidium thiocyanate (Sigma) plus sarkosyl. DNA was extracted with ammonium acetate and cold isopropanol. A rapid DNA extraction method (7) was also performed; both DNA obtained were used for the PCR reactions to check results.

The isolates were blindly tested by three methods (SAST 1, SAST 2 and PCR). Each isolate was pre-tested with a $0.85 \% \mathrm{NaCl}$ solution containing $0.5 \%$ formol to prevent autoagglutination. Monovalent serotype-specific rabbit antisera (specific for serotypes a through f), (Difco) were utilized. Method 1 (SAST 1) that uses a serotype b-specific antiserum for screening, was performed by suspending a full loop of bacterial growth into 50 $\mu \mathrm{l}$ of a serotype b-specific antiserum, and thoroughly mixed by rocking the slide for $1 \mathrm{~min}$. In this method, the serotype b-specific antiserum was used for the initial screening; a positive agglutination result was considered to indicate serotype b. If the isolate was not reactive, it was tested with the remaining antisera (a through $\mathrm{f}$ ). When a negative reaction towards all antisera in the set was observed, the strain was considered NTHi. Method 2 was performed with all antisera in parallel, as indicated in the Difco serological antiserum sheets: initially with $\mathrm{Hi}$ polyvalent antiserum and afterwards with $\mathrm{Hi}$ monovalent antisera type a to $\mathrm{f}$, in parallel. For both SAST methods, the intensity of the reaction was recorded by symbols representing the absence of, or different grades of agglutination: (-, negative; +, slow and weak; ++++ , rapid, with formation of large clumps). Positive agglutination was defined as the production of large clumps (+++ or ++++) with one specific antiserum only. The isolate was considered NTHi when negative agglutination results with the complete set of antisera or weak reactions with at least two antisera (nonspecific reaction) were observed. When positive agglutination occurred with at least two specific antisera, the isolate was considered polyagglutinated (1).

Primers specific for the bexA gene (primers $\mathrm{H} 1$ and $\mathrm{H} 2$ ) (4), required for capsular export, were used to differentiate NTHi from encapsulated isolates. Primers and PCR conditions have been previously described $(4,7)$.

Table 1 shows the prevalence of capsule types found among $H i$ by the three methods studied. Significant differences in the prevalence rates were found for capsule type b SAST 1 (25.8\%) versus SAST $2(1.1 \%)$ and PCR $(1.1 \%)$ respectively. Also, divergent rates of NTHi isolates were identified by SAST 1 (74.1\%) compared with SAST $2(72.1 \%)$ and PCR (93.5\%). Serotypes d, e and f were identified by SAST 2 but not by

Table 1. Comparison between the frequencies of capsule types for $93 \mathrm{H}$. influenzae nasopharyngeal isolates obtained from children attending day-care centers in Ribeirão Preto from November 2002 to November 2003, according to the SAST 1, SAST 2 and PCR methods.

\begin{tabular}{ccccccc}
\hline \multirow{2}{*}{$\begin{array}{c}\text { H. influenzae } \\
\text { capsule type }\end{array}$} & \multicolumn{3}{c}{$\begin{array}{c}\text { No. (\%) of isolates with the } \\
\text { indicated capsule type by: }\end{array}$} & & \multicolumn{2}{c}{$\begin{array}{c}\text { No. (\%) of isolates which } \\
\text { PCR results agree with: }\end{array}$} \\
\cline { 2 - 4 } \cline { 6 - 7 } & SAST method 1 & SAST method 2 & PCR & & SAST method 1 & SAST method 2 \\
\hline $\mathrm{a}$ & 0 & 0 & 0 & & $0(100)$ & $0(100)$ \\
$\mathrm{b}$ & $24(25.8)$ & $1(1.1)$ & $1(1.1)$ & & $1(4.1)$ & $1(100)$ \\
$\mathrm{c}$ & 0 & $2(2.1)$ & 0 & & $0(100)$ & $0(0)$ \\
$\mathrm{d}$ & 0 & $3(3.2)$ & $1(1.1)$ & & $0(0)$ & $1(33.3)$ \\
$\mathrm{e}$ & 0 & $2(2.1)$ & $1(1.1)$ & & $0(0)$ & $1(50.0)$ \\
$\mathrm{f}$ & 0 & $2(2.1)$ & $3(3.2)$ & & $0(0)$ & $2(66.6)$ \\
NTHi & $69(74.1)$ & $67(72.1)$ & $87(93.5)$ & & $69(100)$ & $67(77.0)$ \\
Polyagglutination & 0 & $16(17.3)^{\mathrm{a}}$ & 0 & & $\mathrm{NA}^{\mathrm{b}}$ & $\mathrm{NA}^{\mathrm{b}}$ \\
\hline Total isolates & 93 & 93 & 93 & $70(75.2)$ & $72(93.5)^{\mathrm{c}}$ \\
\hline
\end{tabular}

${ }^{\mathrm{a}}$ sixteen isolates identified as polyagglutinating by SAST 2 were identified as NTHi by PCR; ${ }^{\mathrm{b}}$ Not applicable; ${ }^{\mathrm{c}}$ sixteen isolates polyagglutinated were excluded from the agreement rate. 
SAST 1 method. Sixteen isolates identified as polyagglutinated were typed as NTHi by PCR. The overall rate of agreement in capsule typing of $H i$ isolates between SAST 1 or 2 and PCR was of $75.2 \%$ or $93.5 \%$ respectively (Table 1 ). Thus an increase of $18.3 \%$ in the agreement rate was achieved by using SAST 2 . The most important discrepant result was of the 23 isolates falsely identified as serotype b by SAST 1 , and afterwards identified as NTHi or another serotype by PCR. Five isolates classified as NTHi or serotype b by SAST 1 were identified by PCR as type $\mathrm{f}$ ( 3 isolates), type $\mathrm{d}$ ( 1 isolate) and type e (1 isolate). When the results of SAST 2 and PCR were compared, 6 discrepant types were found: 1 isolate identified as NTHi by SAST 2 was typed as type $\mathrm{f}$ by PCR; 2 isolates identified as type $\mathrm{d}$ were typed as NTHi by PCR, 2 isolates identified as type c were typed as NTHi by PCR and 1 isolate identified as type e was classified as NTHi by PCR (Table 1).

These results demonstrate the limitations of SAST1 for $\mathrm{Hi}$ serotyping in comparison with the results provided by PCR. This difference was attributed to the use of a single type bspecific antiserum for screening, leading us to consider every form of agglutination as a $H i b$ positive reaction, a finding complicated by the weak intensity of agglutination in the nasopharyngeal isolates from healthy subjects. Thus, SAST 1 overestimated the serotype $b$ isolates, a finding which explains the poor agreement between SAST 1 and PCR for serotype $b$. This result is in accordance with those reported by La Claire et al. (7) and Bokerman et al. (1). However, as previously reported (1), the use of all antisera in parallel (SAST 2), significantly improved capsule type agreement with PCR.

The impact of the Brazilian program of Hib vaccination, initiated in 1999, should be evaluated among healthy children. We therefore stress the importance of using the SAST 2 method for the accurate estimation of $H$. influenzae type $\mathrm{b}$ in colonized children, and the use of PCR to confirm the results.

\section{ACKNOWLEGDEMENTS}

This work was supported by a research grant from FAPESP (01/07595-2). Swabs were kindly provided by Copan, Italy. The authors thank the Ribeirão Preto Municipal Secretaries of Health and Education, the managers of day-care centers participating in this study, and also Rosemeire C. Zanella from the Adolfo Lutz Institute for advice on serotyping methods and PCR reactions.

\section{RESUMO}

\section{Comparação de dois métodos de sorotipagem de cápsula por aglutinação em lamina e o método de PCR para a caracterização de sorotipos de Haemophilus influenzae}

Noventa e três isolados nasofaringeanos de $H$. influenzae foram sorotipados através de 2 métodos de aglutinação em lamina (SAST 1 e SAST 2) e os resultados foram comparados com a sorotipagem por PCR. SAST 1 apresentou uma baixa correlação com os resultados obtidos por PCR $(75,2 \%)$ enquanto que SAST 2 mostrou uma melhor concordância com os resultados da técnica molecular $(93,5 \%)$. Estes resultados indicam que SAST 2 pode ser um método alternativo para a correta detecção de $H$. influenzae tipo b.

Palavras-chave: Haemophilus influenzae, métodos de sorotipagem, PCR

\section{REFERENCES}

1. Bokerman, S.; Zanella, R.C.; Lemos, A.P.; Andrade, A.L.S.S.; Brandileone, M.C.C. Evaluation of methodology for seroytping invasive and nasopharyngeal isolates of Haemophilus influenzae in the ongoing surveillance in Brazil. J. Clin. Microbiol., 41, 55465550, 2003.

2. Campos, J.M. Haemophilus. In: Murray, P.R.; Baron, E.; Fallen, M.A.; Tenover, F.C.; Yolken, R.H. eds. Manual of clinical microbiology. $7^{\text {th }}$ ed. Washington, DC: ASM Pres, 604-613, 1999.

3. Dunais, B.; Pradier, C.; Carsenti, H.; Sabah, M.; Mancini, G.; Fontas, E.; Dellamonica, P. Influence of child care on nasopharyngeal carriage of Streptococus pneumoniae and Haemophilus influenzae. Pediatr. Infect. Dis. J., 22, 589-592, 2003.

4. Falla, T.J.; Crook, D.W.M.; Brophy, L.N.; Maskell, D.; Kroll, J.S.; Moxon, E.R. PCR for capsular typing of Haemophilus influenzae. J. Clin. Microbiol., 32, 2382-2386, 1994.

5. Farjo, R.S.; Foxman, B.; Patel, M.J.; Zhang, L.; Pettigrew, M.M.; Mc Coy, S.I.; Marrs, C.F.; Gilsdorf, J.R. Diversity and sharing of Haemophilus influenzae strains colonizing healthy children attending day-care centers. Pediatr. Infect. Dis. J., 23, 41-46, 2004.

6. Hviid, A.; Melbye, M. Impact of routine vaccination with a conjugate Haemophilus influenzae type b vaccine. Vaccine, 22, 378-382, 2004.

7. LaClaire, L.L.; Tondella, M.L.C.; Beal, D.S.; Noble, C.A.; Raghunathan, P.L.; Rosesstein, N.E.; Popovic, T.; Active Bacterial Core Surveillance Team Members. Identification of Haemophilus influenzae serotypes by standard slide agglutination serotyping and PCR-based capsule typing. J. Clin. Microbiol., 41, 393-396, 2003.

8. Peerbooms, P.G.H.; Engelen, M.N.; Stokman, D.A.J.; van Benthem, B.H.B.; van Weert, M.L.; Bruisten, S.M.; van Belkum, A.; Coutinho, R.A. Nasopharyngeal carriage of potential bacterial pathogens related to day care attendance, with special reference to the molecular epidemiology of Haemophilus influenzae. J. Clin. Microbiol., 40, 2832-2836, 2002.

9. Peltola, H. Worlwide Haemophilus influenzae type b disease at the beginning of the 21st century: global analysis of the disease burden 25 years after the use of the polysaccharide vaccine and a decade after the advent of conjugates. Clin. Microbiol Rev., 13, 302-317, 2000.

10. Pitcher, D.G.; Saunders, N.A.; Owen, R.J. Rapid extraction of bacterial genomic DNA with guanidine thiocyanate. Lett Appl. Microbiol., 8, $151-156,1989$.

11. Redmond, S.R.; Pichichero, M.E. Haemophilus influenzae type b disease: an epidemiological study with special reference to day-care centers. JAMA, 252, 2581-2584, 1984.

12. Watt, J.P.; Levine, O.S.; Mathuram, S. Global reduction of Hib disease: What are the next steps? J. Pediatr., 143(Suppl.), S163-S187, 2003. 